OPEN ACCESS

Edited by:

Petros Christopoulos,

Heidelberg University Hospital,

Germany

Reviewed by:

Mara Brancaccio,

University of Turin, Italy

Gabriele Multhoff,

Technical University of Munich,

Germany

Chunqing Guo,

Virginia Commonwealth University,

United States

*Correspondence:

Zarema Albakova

zarema.albakova14@gmail.com

Specialty section:

This article was submitted to

Cancer Immunity

and Immunotherapy,

a section of the journal

Frontiers in Immunology

Received: 16 October 2021 Accepted: 16 November 2021 Published: 30 November 2021

Citation:

Albakova Z and Mangasarova Y (2021) The HSP Immune Network in Cancer.

Front. Immunol. 12:796493. doi: 10.3389/fimmu.2021.796493

\section{The HSP Immune Network in Cancer}

\author{
Zarema Albakova $^{1 *}$ and Yana Mangasarova ${ }^{2}$ \\ ${ }^{1}$ Department of Immunology, Lomonosov Moscow State University, Moscow, Russia, ${ }^{2}$ National Research Center for \\ Hematology, Moscow, Russia
}

Heat shock proteins are molecular chaperones which support tumor development by regulating various cellular processes including unfolded protein response, mitochondrial bioenergetics, apoptosis, autophagy, necroptosis, lipid metabolism, angiogenesis, cancer cell stemness, epithelial-mesenchymal transition and tumor immunity. Apart from their intracellular activities, HSPs have also distinct extracellular functions. However, the role that HSP chaperones play in the regulation of immune responses inside and outside the cell is not yet clear. Herein, we explore the intracellular and extracellular immunologic functions of HSPs in cancer. A broader understanding of how HSPs modulate immune responses may provide critical insights for the development of effective immunotherapies.

Keywords: heat shock proteins, tumor immunity, immunotherapy, cancer, extracellular HSPs

\section{INTRODUCTION}

Heat shock proteins (HSPs) are molecular chaperones classified into several families such as HSP70, HSP90, HSP110, HSPB, HSP40 and chaperonins (1). HSPs are induced upon various cellular stresses including heat, radiation, infectious agents, heavy metal toxicity and hypoxia (2). Recent data have emerged suggesting that HSP functions are not only dependent on the stimuli triggering their expression, but also the compartment in which they are present (3-9). HSPs have been implicated in the regulation of apoptosis, necroptosis, autophagy, cancer cell stemness, epithelial to mesenchymal transition, lipid metabolism, angiogenesis and tumor immunity, supporting tumor growth and development (10-14). Originally described as intracellular chaperones, HSPs have also been found in extracellular milieu. In extracellular environment, presence of HSPs associates with tumor aggressiveness, resistance to therapy and poor clinical outcome (15-17). Various HSPs have been detected in liquid biopsies of cancer patients, stimulating the research towards the discovery of HSP-based specific biomarker of cancer [reviewed in (18)] (19-32).

Increasing evidence has shown that extracellular HSPs are capable of triggering immune responses, which was further translated into the development of various HSP-based immunotherapies (33-39). Furthermore, several studies reported that different populations of immune cells including natural killer (NK) cells, T cells, monocyte-derived dendritic cells (mDCs), platelets and neutrophils may release HSPs in extracellular vesicles [reviewed in (18)] (40-46). This review will focus on immunologic functions of HSPs in tumor immunity. Further elucidating the role of HSPs in tumor immunology, may provide the basis for future discoveries of novel and effective HSP-based immunotherapies. 


\section{IMMUNE FUNCTIONS OF HSPS IN CANCER}

HSPs are localized in various cellular compartments including cytosol, endoplasmic reticulum (ER) and mitochondria, where they play compartment-specific cellular functions. For example, ER-resident HSP90 chaperone glucose-regulated protein 94 (GRP94, also known as Gp96) plays critical role in unfolded protein response (UPR) while mitochondria-resident HSP90 chaperone tumor necrosis factor receptor-associated protein 1 (TRAP1) is involved in mitochondrial bioenergetics, contributing to apoptosis resistance, cancer cell stemness and Warburg phenotype (47-50). Apart from their compartmentspecific role, HSPs play an important role in the regulation of immune responses. Bae and colleagues reported that HSP90 inhibition reduces surface expression of CD3, CD4, CD8, CD28, CD 40L, CD25 and $\alpha \beta$ on T cells and activating receptors such as CD2, CD11a, CD94, NKp30, NKp44, NKp46, KARp50.3 on the surface of NK cells (51). HSP90 inhibition reduces $\mathrm{NK}$ and $\mathrm{T}$ cell proliferation, NK cell cytotoxic activity and IFN- $\gamma$ production by $\mathrm{T}$ and $\mathrm{NK}$ cells $(51,52)$. By contrast, ER HSP90 member GRP94 does not affect cytolytic activity of NK cells towards tumors but rather acts indirectly via antigen presenting cells (APC) selectively enhancing cytokine production (53). Earlier studies showed that HSPs carry tumor-derived peptides that may induce T- cell mediated response while HSPs may stimulate NK cells in the absence of antigenic peptide $(45,46)$. In this regard, Multhoff and colleagues reported that pre-treatment of NK cells with stress-inducible HSP70 or HSP70-derived TKD peptide in combination with IL-2 or IL-15 induces NK cell proliferation and cytolytic activity (54, 55). NK cells pre-stimulated with IL-2 and TKD in combination with anti-PD-1 antibody improves cytolytic activity of NK cells against tumor cells and inhibits tumor growth in vivo (56). Notably, adoptive therapy with autologous NK cells ex vivo stimulated with TKD and IL-2 increased the number of activated NK cells in the blood of patients with membranepositive HSP70 non-small cell lung carcinoma after radiochemotherapy in phase II clinical trial (36). Taken together, HSPs regulate the expression of critical antigens and co-stimulatory molecules on $\mathrm{T}$ cells and key activating receptors on NK cells while HSPs inhibition impairs proliferation and cytotoxic activity of $\mathrm{T}$ and NK cells, suggesting that HSPs are critical for the regulation of the phenotype and functional activity of $\mathrm{T}$ and NK cells.

HSP70s may also act as damage-associated molecular patterns (DAMPs) and elicit anti-tumor response which with long-term exposure results in immune tolerance (11, 57-59). Acting as a DAMP, HSP70 negatively regulates multimeric cytosolic protein complex - the Nod-like receptor protein 3 (NLRP3) inflammasome (60). NLRP3 is an intracellular sensor that detects endogenous danger signals, leading to the assembly of NLRP3 inflammasome, which further activates the caspase-1dependent release of pro-inflammatory cytokines such as IL-1 $\beta$ and IL-18 (61). In this regard, HSP70 deficiency leads to the activation of caspase- 1 and subsequent production of IL- $1 \beta$ by bone marrow-derived macrophages (60). Conversely, HSP90 downregulation inhibits priming and activation of NLRP3 inflammasome (62). HSP90 inhibition in macrophages showed to affect an inflammatory response to lipopolysaccharide and IFN $\gamma$, resulting in reduced secretion of IL-6, TNF $\alpha$ and nitric oxide (NO) (63). Since HSP90 stabilizes IKK complex, the expression of IKK was also diminished, leading to inactivation of NF-kB pathway (63-65). Therefore, the overexpression of HSP70 and HSP90 in the cytosol will either inhibit or activate NLRP3 inflammasome, respectively, suggesting that functions of immune cells that express NLPR3 inflammasome (e.g. macrophages, monocytes and $\mathrm{CD} 4+\mathrm{T}$ cells) may be affected by HSPs up- or down-regulation. For example, inflammasome activation in CD4+T cells leads to increased IFN $\gamma$ secretion and $\mathrm{T}$ helper (Th)1 differentiation, and, therefore, various HSP90 and HSP70 inhibitors may differently affect Th1 response, however, this warrants further investigation (66).

HSPs such as stress-inducible cytosolic HSP90 family member HSP90 $\alpha$ (HSP90AA1) and constitutive cytosolic HSP90 member HSP90 $\beta$ (HSP90AB1) also play an important role in antigen presentation. Ichiyanagi and co-workers demonstrated that heat shock factor -1 (HSF-1)-deficient DCs are less efficient in cross-presentation of antigens (67). Furthermore, HSP90 $\alpha$-deficient DCs showed reduction in cytosolic translocation of antigens $(65,68)$. Along this line, Kunisawa and colleagues reported that, in contrast to HSP90 $\beta$, specific inactivation of HSP90 $\alpha$ leads to a loss of proteolytic intermediates and reduced presentation of the final peptide on the cell surface of MHC I molecule (69). Besides MHC class I antigen presentation, HSP90 inhibition also downregulates MHC II-mediated presentation of endogenous and exogenous peptides by APC (70). Additionally, constitutive HSP70 family member HSC70 is also involved in MHC class II antigen presentation pathway $(71,72)$. HSC70 interacts with MHC II for delivering clients to lysosomes (73). Cumulatively, these studies suggest a major role of HSPs in MHC I and MHC II antigen presentation, suggesting that HSP inhibition may affect immune responses in various treatment scenarios.

HSPs are also implicated in the regulation of immune checkpoints. Song and colleagues reported that HSP90 $\alpha$ inhibition sensitizes tumor cells to anti-PD-1 blockade (74). In a recent study, Zavareh and co-workers (2021) demonstrated that HSP90 inhibition by ganetespib reduces surface expression of PD-L1 on MC-38 tumor cells and human monocyte-derived macrophages (75). Mechanistically, HSP90 inhibition downregulates c-MYC and signal transducer and activator of transcription 3 (STAT3), leading to the reduction of PD-L1 surface expression (75). In this regard, Marzec and colleagues demonstrated that HSP90 client protein nucleophosmin/ anaplastic lymphoma kinase (NPM/ALK) induced PD-L1 surface expression via the activation of STAT3 in T cell lymphoma (76). Since c-MYC and NPM/ALK are HSP90 client proteins, it appears that HSP90 inhibition downregulates PD-L1 surface expression via the degradation of HSP90 client proteins (c-MYC and NPM/ALK). Notably, anti-PD-L1 in combination with HSP90 inhibitor ganetespib showed higher anti-tumor activity than anti-PD-L1 alone in syngeneic mouse 
models (77). Furthemore, ganetespib in combination with antiPD-L1 showed to increase the number of activated CD8+ T cells (75). Earlier, Mbofung and colleagues (2017) demonstrated that mice treated with ganetespib and anti-CTLA4 increased the number of $\mathrm{CD} 8+\mathrm{T}$ cells while decreasing the number of $\mathrm{T}$ regulatory cells (78).Furthermore, ganetespib upregulated interferon response genes, sensitizing human melanoma cells to T-cell mediated killing (78). D'Arrigo and colleagues reported that downregulation of the spliced form of HSP90 cochaperone FKBP51 (sFKBP51) reduces PD-L1 expression in glioma cells (79). In another study, HSP70 ER member glucose-regulated protein 78 (GRP78) downregulation decreased PD-L1 expression in breast cancer cells (80). Taken together, HSPs regulate the expression of multiple immune checkpoints including PD-L1 and PD-L2 while combination of anti-PD-L1, anti-PD-1, antiCTLA4 with HSP90 inhibitor showed promising results in mouse models, suggesting that HSP inhibitors may further improve immunotherapy.

\section{EXTRACELLULAR HSPs AND TUMOR IMMUNITY}

In extracellular environment HSPs exist in several forms either secreted or membrane-bound. In this regard, Multhoff and colleagues demonstrated that surface expression of HSP70 on tumors does not involve classical ER-Golgi transport pathway for its membrane localization (81). Mambula and Calderwood reported that HSP70 can be released via lysosomal endosomes $(82,83)$. Authors also showed that HSP70 release involves the entry of HSP70 into endolysosomes via ATP-binding cassette (ABC) transporters $(82,83)$. HSP70 may also interact with either globotriaoslyceramide or phosphatidylserine for the anchorage of HSP70 in the plasma membranes of tumors $(84,85)$. Another mechanism by which HSPs are secreted into extracellular milieu involves the release of exosomes derived from multivesicular bodies (86-89). In this regard, several studies reported that HSPs on the surface of tumor-derived exosomes promote tumor growth by suppressing immune responses $(90,91)$.

\section{Extracellular HSP90}

Ullrich and co-workers (1986) reported the expression of tumorspecific transplantation antigen on the surface of tumor cells which they identified as HSP90 (92). Immunization of mice with this antigen inhibited tumor growth, suggesting that extracellular HSP90 (eHSP90) contributes to anti-tumor immunity $(92,93)$. Hostile tumor microenvironment leads to chronic ER stress, resulting in the elevation of extracellular HSPs. In this regard, Tramentozzi and colleagues observed high expression of extracellular GRP94-IgG complexes in the plasma of cancer patients (94). GRP94 alone or bound to IgG promotes angiogenesis, MMP-9 expression and extracellular release of HSP90 $\alpha$ and HSP70 in human umbilical vein endothelial cells (HUVECs) (94-96). Authors showed that GRP94 alone may promote angiogenic transformation via stimulation of ERK1/ ERK2 pathway (96). eGRP94 also induces maturation of mDCs, increasing surface expression of CD86 and CD83 (97). GRP94treated mDCs strongly induces $\mathrm{T}$ cell proliferation (97). Interaction of CD91 with GRP94 leads to increased secretion of several inflammatory cytokines such as IL- $1 \beta$, IL- 6 and TNF- $\alpha$ by RAW264.7 cells (98). Dai and colleagues reported that GRP94 on the surface of tumor cells also induces CD4+ and CD8+ T cell memory response (99). eGRP94 facilitates cross-presentation of MHC class I and elicits CD8+ T cell response (100). Even though GRP94 facilitates the presentation of MHC class II-restricted peptides, CD4+T cells are not capable of secreting Th1 and Th2 effector cytokines (100).Immunization with autologous tumorderived GRP94 of mice bearing methylcholanthrene-induced fibrosarcomas effectively induced anti-tumor response on day 7 after tumor challenge and was less effective when the treatment was started on day 9 after tumor challenge (101). DCs primed with lung cancer-derived GRP94 also elicited anti-tumor response in cytotoxic T lymphocytes (CTL) and NK cells (102). On DCs, GRP94 interacts with TLR-2 and TLR-4, leading to increased expression of CD86 and secretion of IL-12 and TNF- $\alpha(103,104)$. Intriguingly, eGRP94 also promotes the expression of Foxp3, IL-10 and TGF- $\beta 1$ in T regulatory cells (T regs) via TLR2/TLR4- mediated NF-kB signaling pathway activation (105). GRP94-peptide complex interaction with TLRs appears to be critical for the stimulation of cytotoxic $T$ cell response (106). Additionally, GRP94 also activates NLRP3 inflammasome in APCs, leading to the IL-1 $\beta$ secretion (107). Taken together, eGRP94 possesses both pro- and anti-tumor functions. On the one hand, eGRP94 promotes angiogenesis and supports $\mathrm{T}$ reg suppressive function and, on the other hand, eGRP94 induces DC maturation and enhances CTL response.

Intriguingly, Chen and colleagues demonstrated that expression of stress-inducible HSP $90 \alpha$ on the surface of tumor-cell released autophagosomes (TRAPs) promotes IL-6 production by CD4+ T cells via TLR2-Myeloid differentiation primary response protein 88 (MyD88)- NF-kB signalling pathway (108). Autocrine IL-6 further enhanced IL-10 and IL21 production by CD4+T cells via STAT3, supporting tumor growth and metastasis (108). In another study, eHSP90, IL-6 and IL- 8 secreted by macrophages activated JAK2-STAT3 in pancreatic ductal epithelial cells, leading to malignant transformation of these cells (109). Recent data have emerged showing that monoclonal antibodies specifically targeting eHSP90 $\alpha$ inhibited tumor formation via blocking the interaction of eHSP90 with matrix metalloproteinase 2 (MMP2) and MMP9 (110, 111). Since eHSP90 $\alpha$ has a profound immunosuppressive effects, it may be further speculated that specific blocking of eHSP $90 \alpha$ by monoclonal antibodies will dampen IL-6-dependent inhibitory effects on $\mathrm{CD} 4+\mathrm{T}$ and $\mathrm{CD} 8+\mathrm{T}$ cell function while also blocking IL-10 production by $\mathrm{T}$ and $\mathrm{B}$ cells, however, this warrants further investigation (108).

\section{Extracellular HSP70}

eHSP70s have a dual role in the regulation of immune responses, where HSP70 can act as immune suppressor and immune activator (Figure 1). Such equivocal function of eHSP70 largely depends on the type of immune cell on which eHSP70 exerts its 


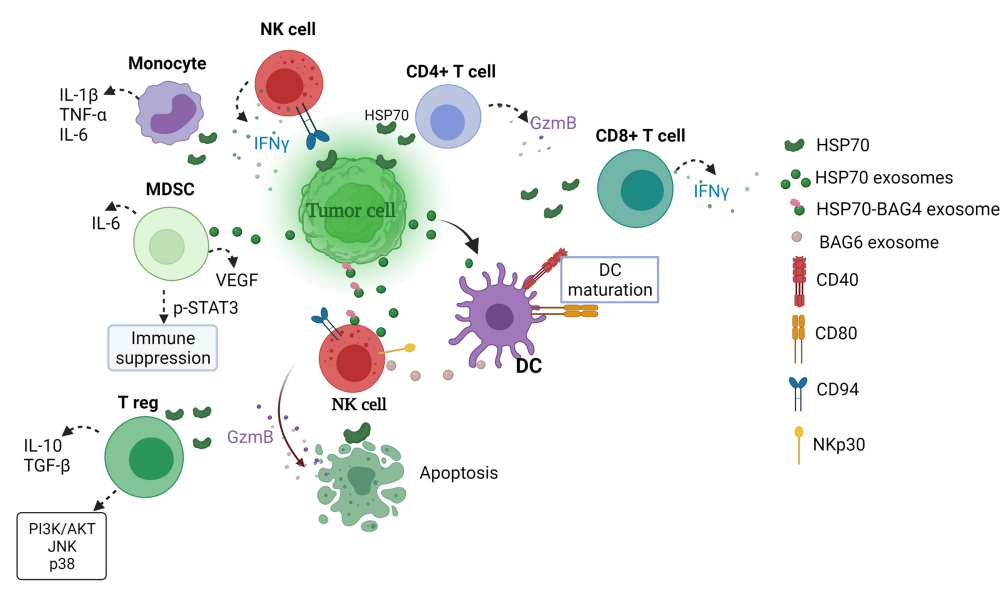

FIGURE 1 | Extracellular HSP70 immune network in cancer. eHSP70s enhance NK cytotoxicity, DC maturation, induce strong CD4+ and CD8+ T cell responses and cytokine secretion by monocytes and enhance immunosuppressive activity of MDSCs and T regs (54, 112-118). MDSCs, myeloid-derived suppressor cells; $T$ reg, $T$ regulatory cell; GzmB, granzyme B; DC, dendritic cells; IFN $\gamma$, interferon $\gamma$, BAG, BCL2-associated athanogene; IL-6, interleukin-6; TNF- $\alpha$, tumor necrosis factor $\alpha$; VEGF, vascular endothelial growth factor; TGF- $\beta$, transforming growth factor $\beta$; PI3K/AKT, phosphatidylinositol 3-kinase (PI3K)-serine/threonine protein kinase (AKT), JNK, c-Jun $\mathrm{N}$-terminal kinase; STAT3, signal transducer and activator of transcription.

action. Multhoff and colleagues demonstrated that surface form of cytosolic stress-inducible HSP70 member acts as recognition structure for NK cells (119). Pre-treatment of NK cells with human recombinant HSP70 enhanced NK cell proliferation and IFN- $\gamma$ production (54). Gastpar and co-workers have shown that CD94+NK cells migrate towards HSP70-surface positive tumors (112). Later, same research team demonstrated that the expression of HSP70 and co-chaperone BCL2-associated athanogene 4 (BAG4) on tumor-derived exosomes enhances migration and cytolytic activity of NK cells $(113,118)$. The expression of BAG6 on the surface of DCs-derived exosomes also activates NKp30 receptor (120). Following treatment with various chemotherapeutic agents, HSP-bearing exosomes released by hepatocellular carcinoma cells stimulates NK cell cytotoxicity and granzyme B production (121).

The ability of exosomal HSP70 to stimulate anti-tumor responses has been demonstrated with the use of engineered myeloma J558HSP cell line (115). Cells were manipulated to endogenously express P1A tumor antigen and membrane-bound HSP70 (115, 122). J558HSP -derived exosomes ( $\left.\mathrm{EXO}_{\mathrm{HSP}}\right)$ upregulated the expression of CD40 and CD80 and increased the section of IL-1 $\beta$, IL-12, IFN- $\gamma$ and TNF- $\alpha$ by DCs (115). Furthermore, immunization of $\mathrm{BALB} / \mathrm{c}$ mice with $\mathrm{EXO}_{\mathrm{HSP}}$ induced CD4+T cell response and secretion of IL-2 and IFN- $\gamma$, suggesting that $\mathrm{EXO}_{\mathrm{HSP}}$ induces type $1 \mathrm{~T}$ helper response (115). EXO $_{\text {HSP }}$ could also effectively elicit P1A-specific CD8+T cell response (115). In another study, stimulation of $\mathrm{T}$ cells with soluble HSP70 (sHSP70) increased IFN- $\gamma$, IL- 6 and IL- 8 production by CD4+ and IFN- $\gamma$ and IL- 8 by CD8+ cells (114). Notably, pre-stimulation with both HSP70 in combination with IL-2 increased granzyme B secretion by CD4+ and CD8+ T cells (114). Earlier, Blachere and colleagues demonstrated that GRP94/gp96-peptide complexes and HSP70-peptide complexes induce CD8+ T cell response (45).
eHSP70 also regulates immunosuppressive activity of myeloid-derived suppressor cells (MDSCs) and $\mathrm{T}$ regulatory cells ( $\mathrm{T}$ regs) $(116,117)$. Exosomal HSP70 induces STAT3 phosphorylation and increases secretion of IL-6 and vascular endothelial growth factor (VEGF) in MDSCs, thus promoting tumor growth (116). Wachstein and co-workers demonstrated that pre-treatment of T regs with HSP70 upregulated the secretion of IL-10, transforming growth factor $\beta$ (TGF- $\beta$ ) and resulted in phosphorylation of phosphatidylinositol 3-kinase (PI3K)-serine/threonine protein kinase (AKT), c-Jun $\mathrm{N}$ terminal kinase (JNK) and p38 (117).

HSP70 ER homolog GRP78/BiP has also been observed on the surface of tumor cells (123). High GRP78 expression has also been observed on the surface of PBMC subpopulations including CD4+ and CD8+T cells and CD56+ NK cells, following chemotherapy in breast cancer patients (124). Interestingly, eGRP78 increases CD19+ surface expression, upregulates PD-L1 and FasL expression and IL-10 secretion in B cells (125). Notably, CD19+ cells pre-treated with GRP78 and anti-CD40 inhibited the proliferation of CD3/CD28activated $\mathrm{T}$ cells, indicating that GRP78 may induce B regulatory cells (125). In another study, Corrigall and colleagues have reported that eGRP78 increased IL-10 secretion by PBMCs and reduced expression of HLA-DR and CD86 on monocytes (126). Later, same research team showed that mDCs treated with GRP78 increases intracellular indoleamine 2,3- dioxygenase (IDO) level and surface expression of leukocyte immunoglobulin-like receptor subfamily $\mathrm{B}$ member 1 and downregulates HLA-DR and CD86 expression, while retaining CD14 expression (127). T cells treated with such mDCs upregulated the expression of $\mathrm{CD} 4^{+} \mathrm{CD} 25^{\text {high }} \mathrm{CD} 27^{\text {high }}$ and cytotoxic T-lymphocyte antigen (CTLA-4), while no increase in the expression of forkhead box P3 (FOXP3) was observed (127). Therapeutic targeting of surface GRP78 by human IgM monoclonal antibody PAT-SM6 resulted 
in induction of apoptosis and complement-dependent cytotoxicity in de novo and relapsed multiple myeloma $(38,128)$. Along this line, murine IgG antibody C107 targeting GRP78 carboxyl-terminal domain induced apoptosis in vitro and inhibited melanoma growth in vivo $(123,129)$. In another study, Liu and co-workers reported that monoclonal antibody Mab159 binds to the surface GRP78 and triggers GRP78 endocytosis, leading to apoptosis in breast and colon cancer cell lines via inhibiting phosphoinositide 3kinase (PI3K) activity (130).

Pilzer and co-workers demonstrated that mitochondrial HSP70 mortalin interacts with complement C9 (131, 132). Sub-lytic complement attack causes C9 and mortalin release in extracellular vesicles (131). Mechanistically, formation of the complete C5b-C9 membrane-attack complex (MAC) induced the release of mortalin whereas targeting mortalin with antibodies showed to increase cell lysis (131). Thus, authors concluded that mortalin protects cells from complementdependent cytotoxicity (CDC) by removing MAC from the cell surface (131). Later, same research team showed that blocking mortalin sensitizes tumor cells to CDC (133).

eHSP70 may also bind to the surface of human monocytes, leading to intracellular calcium flux, activation of nuclear factor (NF)-kB and increased production of IL- $1 \beta$, TNF- $\alpha$ and IL-6 via NF-kB pathway (134). Taken together, extracellular HSP70s promote proliferation and cytolytic activity of NK cells, DC maturation, CD4+ and CD8+ T cell responses, protect cancer cell from CDC as well as enhances induction of tolerogenic DCs, immunosuppressive activity of MDSCs and generation of $\mathrm{T}$ regulatory cells. Therefore, future discoveries of therapies targeting extracellular form of HSP70 should take into account equivocal effect of HSP70 family members on different components of immune system.

\section{Extracellular HSP110 and GRP170}

HSP110 represents a family of chaperones that is distantly related to HSP70 family (1). Recent studies have emphasized the role of extracellular HSP110 and its ER member GRP170 in the regulation of immune responses. In this regard,
Berthenet and colleagues reported that eHSP110 promotes macrophage polarization towards M2 phenotype via TLR4 pathway while HSP110 inhibition reverses this effect (135). In the extracellular space, GRP170 secreted by B16 melanoma cells acts as a danger signal, inducing the production of IL-1 $\beta$ and TNF $\alpha$ by DCs and eliciting antigen-specific CTL response by cross-priming (136-138). Along this line, immunization of mice with tumor-derived GRP170 induces potent CD8+T cell response (139).

\section{Extracellular HSP60}

HSP60 plays critical role in the regulation of innate and adaptive immune responses (Figure 2) (141). In response to HSP60, macrophages and DCs secrete inflammatory cytokines such as IFN $\alpha$, TNF- $\alpha$, IL-12, IL-15, IL-6, IL- $1 \beta$ and NO (Figure 2A) (141, 142). eHSP60 induces the maturation of bone marrow-derived dendritic cells (BMDCs) via TLR4 and activation of allogeneic $\mathrm{T}$ cells, resulting in the production of Th1-promoting cytokines (140). Feng and colleagues demonstrated that the expression of HSP60 on the surface of apoptotic tumor cells activates DCs and induces cytotoxic T cell response, suggesting that the HSP60 on tumor cells may promote potent anti-tumor $\mathrm{T}$ cell response mediated by APC $(2,146)$. By contrast, T cells pre-treated with HSP60 downregulate Th1-associated transcription factors such as Tbet, NFATp and NF-kB, inhibiting the secretion of IFN- $\gamma$ and TNF- $\beta$, and upregulate GATA-3, leading to increased secretion of Th2-associates cytokines such as IL-10, IL-4 and IL-13 (Figure 2B) (143). eHSP60 also increases the expression of suppressor of cytokine signalling 3 (SOCS3) via TLR2 and STAT3, thus inhibiting $\mathrm{T}$ cell chemotaxis towards stromal cellderived factor-1 $\alpha$ (SDF-1 $\alpha)$ (147). Activated T cells can also present HSP60 by MHC molecules to anti-ergotypic T regulatory cells, resulting in the secretion of IFN- $\gamma$ and TGF $\beta 1$ by anti-ergotypic T cells (Figure 2B) (144). Of note, co-stimulation in the form of CD80, CD86 and CD28 is required for the activation of anti-ergotypic $\mathrm{T}$ cells (144). Additionally, anti-ergotypic $\mathrm{T}$ regulatory cells decrease the
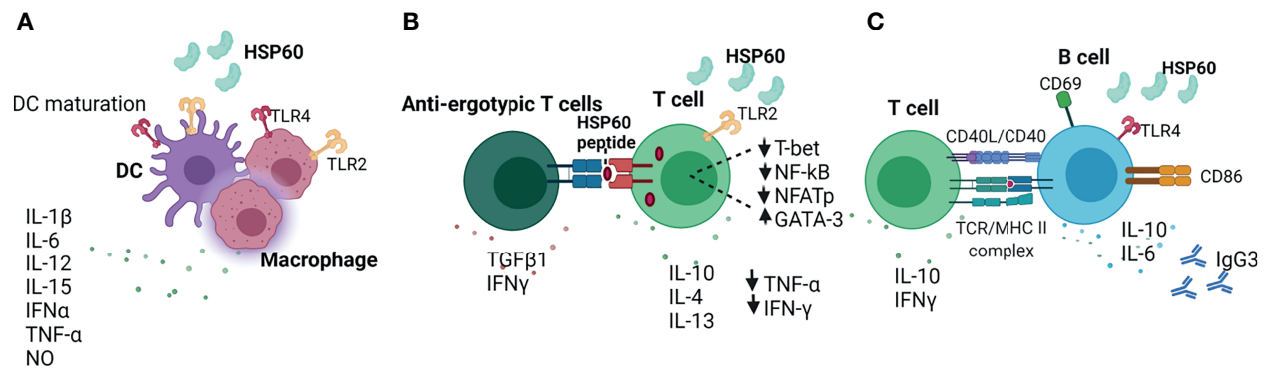

FIGURE 2 | Extracellular HSP60 immune network. (A) HSP60 induces DC maturation and secretion of inflammatory cytokines (140-142). (B) eHSP60 downregulates Th1-associated transcription factors (T-bet, NF-kB, NFATp) and upregulates GATA3, leading to decreased secretion of TNF- $\alpha$ and IFN- $\gamma$ and increased secretion of IL-10, IL-4, IL-13 (143). Activated T cells can present HSP60 via MHC molecules to anti-ergotypic T cells, leading to the production of IFN $\gamma$ and TGF $\beta 1$ by anti-ergotypic T regulatory cells (144). (C) HSP60 activates B cells via TLR4-MyD88 signaling pathway, leading to the production of IL-10, IL-6 and IgG3 (145). TLR4, Toll-like receptor 4; NO, nitric oxide, CD4OL; CD40 ligand; TCR, T cell receptor; MHC II, major histocompatibility complex; IgG3, Immunoglobulin G3; Nf-kB; nuclear factor kappa B; NFAT, nuclear factor of activated T cells. 
secretion of IFN $\gamma$ by effector T cells in vitro $(141,144)$. eHSP60 also stimulates the secretion of IL-10, IL-6, IgG3 and upregulates the expression of MHC class II, CD69, CD86 and CD40 in B cells (145). Interaction of eHSP60-treated B cell with $\mathrm{T}$ cells leads to the IFN $\gamma$ and IL-10 production by $\mathrm{T}$ cells (Figure 2C) (145).

In the extracellular milieu, HSP60 released by B16 melanoma cells promotes the secretion of immunosuppressive cytokines and chemokines including IL-6, IL-10, IL-13, TGF- $\beta 1$, CCL-2 and CCR8 via TLR2 and STAT3 activation $(2,148)$. Highly metastatic B16 cells released higher levels of HSP60 resulting in persistent TLR2 and STAT3 activation compared to poorly metastatic B16F1 cells (148). These results provide a mechanistic explanation to the role that extracellular HSP60s play in promoting immunosuppressive tumor microenvironment (2).

\section{Extracellular HSP27}

HSP27 (HSPB1) is a member of small HSP family aberrant expression of which correlates with poor prognosis and resistance to chemotherapy in different types of cancer (1, 149). eHSP27 induces the secretion of immunosuppressive factors including IL-6, IL-10, prostaglandin E2 and proangiogenic cytokines such as IL-8, VEGF-A, IL-1 $\beta$ and TNF- $\alpha$ by human monocytes (150). eHSP27 also induces high level of monocyte chemotactic protein-1 (MCP-1), a chemokine responsible for monocyte recruitment at the tumor sites (150). Moreover, eHSP27 promotes the differentiation of monocytes into macrophages with TAM-like phenotype (150). HSP27differentiated macrophages have reduced expression of $\mathrm{MHC}$ class II, CD86 and increased expression of PD-L1, Ig-like transcript 2 (ILT2) and ILT4 (150). Autologous T cell cocultured with HSP27-differentiated macrophages inhibits T cell proliferation and significantly reduces the secretion of IFN- $\gamma$ and IL-13 by T cells, suggesting that HSP27-differentiated macrophages induce T cell anergy (150).

\section{CONCLUSION AND PERSPECTIVES}

Heat shock proteins are molecular chaperones which have shown to be implicated in various hallmarks of cancer such as apoptosis resistance, angiogenesis, invasion, metastasis, cancer cell stemness and immune tolerance. Apart from their

\section{REFERENCES}

1. Kampinga HH, Hageman J, Vos MJ, Kubota H, Tanguay RM, Bruford EA, et al. Guidelines for the Nomenclature of the Human Heat Shock Proteins. Cell Stress Chaperones (2009) 14(1):105-11. doi: 10.1007/s12192-008-0068-7

2. Gomez CR. Hsp60 in Cancer Immunity: Biological Basis, Diagnostic Potential and Therapeutic Opportunities. In: AAA Asea, P Kaur, editors. Heat Shock Protein 60 in Human Diseases and Disorders. Cham: Springer International Publishing (2019). p. 117-34. doi: 10.1007/978-3-030-23154-5_9

3. Wang F, Bonam SR, Schall N, Kuhn L, Hammann P, Chaloin O, et al. Blocking Nuclear Export of HSPA8 After Heat Shock Stress Severely Alters Cell Survival. Sci Rep (2018) 8(1):16820. doi: 10.1038/s41598-018-34887-6

4. Sun F-C, Wei S, Li C-W, Chang Y-S, Chao C-C, Lai Y-K. Localization of GRP78 to Mitochondria Under the Unfolded Protein Response. Biochem J (2006) 396(1):31-9. doi: 10.1042/BJ20051916 intracellular functions, HSP can also be secreted in extracellular space, where HSPs interact with various components of the immune system. Even though considerable progress has been made in deciphering the role of HSPs in tumor immunity, there is still a lot to be understood. For example, the role of distinct HSP members in the regulation of innate and adaptive immune responses inside and outside the cell in the context of cancer is not clear. Furthermore, the effects of various HSP-based immunotherapies on the release of HSPs in tumor microenvironment and their subsequent effects on immune responses are not yet fully understood. Taking into account that inside the cell HSPs may translocate from their primary locations and acquire different functions, it is also important to understand the effect of HSP-based immunotherapies on intracellular HSPs. Elucidating the role of HSP in the modulation of immune responses may improve current treatment strategies and open new perspectives for the discovery of novel HSP-based immunotherapy approaches.

\section{AUTHOR CONTRIBUTIONS}

ZA: conceptualization and manuscript writing. YM: administrational support. All authors contributed to the article and approved the submitted version.

\section{FUNDING}

This research was funded by RFBR, project number 20315-90081.

\section{ACKNOWLEDGMENTS}

Authors would like to thank Akhmet Albakov for critically reading the manuscript, helpful discussions and funding acquisition. ZA would like to acknowledge the support from the Interdisciplinary Scientific and Educational School of Moscow University "Molecular Technologies of the Living Systems and Synthetic Biology. The figures were created with BioRender.com.

5. Hayashi T, Su T-P. Sigma-1 Receptor Chaperones at the ER- Mitochondrion Interface Regulate Ca2 + Signaling and Cell Survival. Cell (2007) 131(3):596610. doi: 10.1016/j.cell.2007.08.036

6. Ni M, Zhou H, Wey S, Baumeister P, Lee AS. Regulation of PERK Signaling and Leukemic Cell Survival by a Novel Cytosolic Isoform of the UPR Regulator GRP78/BiP. PloS One (2009) 4(8):e6868. doi: 10.1371/ journal.pone.0006868

7. Ni M, Zhang Y, Lee AS. Beyond the Endoplasmic Reticulum: Atypical GRP78 in Cell Viability, Signalling and Therapeutic Targeting. Biochem J (2011) 434(2):181-8. doi: 10.1042/BJ20101569

8. Reddy RK, Mao C, Baumeister P, Austin RC, Kaufman RJ, Lee AS. Endoplasmic Reticulum Chaperone Protein GRP78 Protects Cells From Apoptosis Induced by Topoisomerase Inhibitors: Role of ATP Binding SITE in Suppression of Caspase-7 Activation *. J Biol Chem (2003) 278 (23):20915-24. doi: 10.1074/jbc.M212328200 
9. Matsumoto A, Hanawalt PC. Histone H3 and Heat Shock Protein GRP78 Are Selectively Cross-Linked to DNA by Photoactivated Gilvocarcin V in Human Fibroblasts. Cancer Res (2000) 60(14):3921.

10. Ciocca DR, Calderwood SK. Heat Shock Proteins in Cancer: Diagnostic, Prognostic, Predictive, and Treatment Implications. Cell Stress Chaperones (2005) 10(2):86-103. doi: 10.1379/csc-99r.1

11. Albakova Z, Armeev GA, Kanevskiy LM, Kovalenko EI, Sapozhnikov AM. HSP70 Multi-Functionality in Cancer. Cells (2020) 9:(3). doi: 10.3390/ cells 9030587

12. Mosser DD, Caron AW, Bourget L, Denis-Larose C, Massie B. Role of the Human Heat Shock Protein Hsp70 in Protection Against Stress-Induced Apoptosis. Mol Cell Biol (1997) 17(9):5317-27. doi: 10.1128/mcb.17.9.5317

13. Cook KL, Soto-Pantoja DR, Clarke PAG, Cruz MI, Zwart A, Wärri A, et al. Endoplasmic Reticulum Stress Protein GRP78 Modulates Lipid Metabolism to Control Drug Sensitivity and Antitumor Immunity in Breast Cancer. Cancer Res (2016) 76(19):5657. doi: 10.1158/0008-5472.CAN-15-2616

14. Ono K, Sogawa C, Kawai H, Tran MT, Taha EA, Lu Y, et al. Triple Knockdown of CDC37, HSP90-Alpha and HSP90-Beta Diminishes Extracellular Vesicles-Driven Malignancy Events and Macrophage M2 Polarization in Oral Cancer. J Extracell Vesicles (2020) 9(1):17693731769373. doi: 10.1080/20013078.2020.1769373

15. Balogi Z, Multhoff G, Jensen TK, Lloyd-Evans E, Yamashima T, Jaattela M, et al. Hsp70 Interactions With Membrane Lipids Regulate Cellular Functions in Health and Disease. Prog Lipid Res (2019) 74:18-30. doi: 10.1016/j.plipres.2019.01.004

16. Juhasz K, Lipp A-M, Nimmervoll B, Sonnleitner A, Hesse J, Haselgruebler T, et al. The Complex Function of Hsp70 in Metastatic Cancer. Cancers (Basel) (2014) 6(1):42-66. doi: 10.3390/cancers6010042

17. Pfister K, Radons J, Busch R, Tidball JG, Pfeifer M, Freitag L, et al. Patient Survival by Hsp70 Membrane Phenotype: Association With Different Routes of Metastasis. Cancer (2007) 110(4):926-35. doi: 10.1002/cncr.22864

18. Albakova Z, Siam MKS, Sacitharan PK, Ziganshin RH, Ryazantsev DY, Sapozhnikov AM. Extracellular Heat Shock Proteins and Cancer: New Perspectives. Trans Oncol (2021) 14(2):100995. doi: 10.1016/j.tranon. 2020.100995

19. Seiwert TY, Tretiakova M, Ma PC, Khaleque MA, Husain AN, Ladanyi A, et al. Heat Shock Protein (HSP) Overexpression in Lung Cancer and Potential as a Therapeutic Target. Cancer Res (2005) 65(9 Supplement):559.

20. Suzuki K, Ito Y, Wakai K, Kawado M, Hashimoto S, Seki N, et al. Serum Heat Shock Protein 70 Levels and Lung Cancer Risk: A Case-Control Study Nested in a Large Cohort Study. Cancer Epidemiol Biomarkers \&amp; Prev (2006) 15(9):1733. doi: 10.1158/1055-9965.EPI-06-0005

21. Gráf L, Barabás L, Madaras B, Garam N, Maláti É, Horváth L, et al. High Serum Hsp70 Level Predicts Poor Survival in Colorectal Cancer: Results Obtained in an Independent Validation Cohort. Cancer Biomarkers (2018) 23:539-47. doi: 10.3233/CBM-181683

22. Gunaldi M, Afsar CU, Okuturlar Y, Gedikbasi A, Kocoglu H, Kural A, et al. Elevated Serum Levels of Heat Shock Protein 70 Are Associated With Breast Cancer. Tohoku J Exp Med (2015) 236(2):97-102. doi: 10.1620/tjem.236.97

23. Dakappagari N, Neely L, Tangri S, Lundgren K, Hipolito L, Estrellado A, et al. An Investigation Into the Potential Use of Serum Hsp70 as a Novel Tumour Biomarker for Hsp90 Inhibitors. Biomarkers (2010) 15(1):31-8. doi: 10.3109/13547500903261347

24. Tas F, Bilgin E, Erturk K, Duranyildiz D. Clinical Significance of Circulating Serum Cellular Heat Shock Protein 90 (HSP90) Level in Patients With Cutaneous Malignant Melanoma. Asian Pac J Cancer Prev (2017) 18(3):599_ 601. doi: 10.22034/APJCP.2017.18.3.599

25. Olejek A, Damasiewicz-Bodzek A, Bodzek P, Wielkoszyński T, Zamłyński J, Stołtny P, et al. Concentrations of Antibodies Against Heat Shock Protein 27 in the Sera of Women With Ovarian Carcinoma. Int J Gynecol Cancer (2009) 19:1516-20. doi: 10.1111/IGC.0b013e3181bf425b

26. Oka M, Sato S, Soda H, Fukuda M, Kawabata S, Nakatomi K, et al. Autoantibody to Heat Shock Protein Hsp40 in Sera of Lung Cancer Patients. Jpn J Cancer Res (2001) 92(3):316-20. doi: 10.1111/j.13497006.2001.tb01097.x

27. Bodzek P, Partyka R, Damasiewicz-Bodzek A. Antibodies Against Hsp60 and Hsp65 in the Sera of Women With Ovarian Cancer. J Ovarian Res (2014) 7:30-0. doi: 10.1186/1757-2215-7-30
28. Hamelin C, Cornut E, Poirier F, Pons S, Beaulieu C, Charrier J-P, et al. Identification and Verification of Heat Shock Protein 60 as a Potential Serum Marker for Colorectal Cancer. FEBS J (2011) 278(24):4845-59. doi: 10.1111/ j.1742-4658.2011.08385.x

29. Campanella C, Rappa F, Sciumè C, Marino Gammazza A, Barone R Bucchieri F, et al. Heat Shock Protein 60 Levels in Tissue and Circulating Exosomes in Human Large Bowel Cancer Before and After Ablative Surgery. Cancer (2015) 121(18):3230-9. doi: 10.1002/cncr.29499

30. Wyciszkiewicz A, Kalinowska-Łyszczarz A, Nowakowski B, Osztynowicz K, Michalak S. Expression of Small Heat Shock Proteins in Exosomes From Patients With Gynecologic Cancers. Sci Rep (2019) 9(1):9817. doi: 10.1038/ s41598-019-46221-9

31. Chanteloup G, Cordonnier M, Isambert N, Bertaut A, Hervieu A, Hennequin A, et al. Monitoring HSP70 Exosomes in Cancer Patients' Follow Up: A Clinical Prospective Pilot Study. J Extracell Vesicles (2020) 9 (1):1766192-1766192. doi: 10.1080/20013078.2020.1766192

32. Albakova Z, Norinho DD, Mangasarova Y, Sapozhnikov A. Heat Shock Proteins in Urine as Cancer Biomarkers. Front Med (Lausanne) (2021) 8:743476. doi: 10.3389/fmed.2021.743476

33. Weng D, Calderwood SK, Gong J. Preparation of a Heat-Shock Protein 70Based Vaccine From DC-Tumor Fusion Cells. Methods Mol Biol (2011) 787:255-65. doi: 10.1007/978-1-61779-295-3_19

34. Li Z, Qiao Y, Liu B, Laska EJ, Chakravarthi P, Kulko JM, et al. Combination of Imatinib Mesylate With Autologous Leukocyte-Derived Heat Shock Protein and Chronic Myelogenous Leukemia. Clin Cancer Res (2005) 11 (12):4460-8. doi: 10.1158/1078-0432.Ccr-05-0250

35. Krause SW, Gastpar R, Andreesen R, Gross C, Ullrich H, Thonigs G, et al. Treatment of Colon and Lung Cancer Patients With Ex Vivo Heat Shock Protein 70-Peptide-Activated, Autologous Natural Killer Cells: A Clinical Phase I Trial. Clin Cancer Res (2004) 10(11):3699-707. doi: 10.1158/10780432. Ccr-03-0683

36. Multhoff G, Seier S, Stangl S, Sievert W, Shevtsov M, Werner C, et al Targeted Natural Killer Cell-Based Adoptive Immunotherapy for the Treatment of Patients With NSCLC After Radiochemotherapy: A Randomized Phase II Clinical Trial. Clin Cancer Res (2020) 26(20):5368. doi: 10.1158/1078-0432.CCR-20-1141

37. Stangl S, Gehrmann M, Riegger J, Kuhs K, Riederer I, Sievert W, et al Targeting Membrane Heat-Shock Protein 70 (Hsp70) on Tumors by Cmhsp70.1 Antibody. Proc Natl Acad Sci (2011) 108(2):733-8 doi: 10.1073/pnas.1016065108

38. Rasche L, Duell J, Morgner C, Chatterjee M, Hensel F, Rosenwald A, et al. The Natural Human IgM Antibody PAT-SM6 Induces Apoptosis in Primary Human Multiple Myeloma Cells by Targeting Heat Shock Protein GRP78. PloS One (2013) 8(5):e63414-4. doi: 10.1371/journal. pone.0063414

39. Albakova Z, Mangasarova Y, Sapozhnikov A. Heat Shock Proteins in Lymphoma Immunotherapy. Front Immunol (2021) 12:660085. doi: 10.3389/fimmu.2021.660085

40. Federici C, Shahaj E, Cecchetti S, Camerini S, Casella M, Iessi E, et al Natural-Killer-Derived Extracellular Vesicles: Immune Sensors and Interactors. Front Immunol (2020) 11:262. doi: 10.3389/fimmu. 2020.00262

41. Perez-Hernandez D, Gutiérrez-Vázquez C, Jorge I, López-Martín S, Ursa A Sánchez-Madrid F, et al. The Intracellular Interactome of TetraspaninEnriched Microdomains Reveals Their Function as Sorting Machineries Toward Exosomes. J Biol Chem (2013) 288(17):11649-61. doi: 10.1074/ jbc.M112.445304

42. Kowal J, Arras G, Colombo M, Jouve M, Morath JP, Primdal-Bengtson B, et al. Proteomic Comparison Defines Novel Markers to Characterize Heterogeneous Populations of Extracellular Vesicle Subtypes. Proc Natl Acad Sci USA (2016) 113(8):E968-77. doi: 10.1073/pnas.1521230113

43. García-Silva S, Benito-Martín A, Sánchez-Redondo S, Hernández-Barranco A, Ximénez-Embún P, Nogués L, et al. Use of Extracellular Vesicles From Lymphatic Drainage as Surrogate Markers of Melanoma Progression and BRAF (V600E) Mutation. J Exp Med (2019) 216(5):1061-70. doi: 10.1084/ jem.20181522

44. Dalli J, Montero-Melendez T, Norling LV, Yin X, Hinds C, Haskard D, et al Heterogeneity in Neutrophil Microparticles Reveals Distinct Proteome and 
Functional Properties. Mol Cell Proteomics (2013) 12(8):2205-19. doi: 10.1074/mcp.M113.028589

45. Blachere NE, Li Z, Chandawarkar RY, Suto R, Jaikaria NS, Basu S, et al. Heat Shock Protein-Peptide Complexes, Reconstituted In Vitro, Elicit PeptideSpecific Cytotoxic T Lymphocyte Response and Tumor Immunity. J Exp Med (1997) 186(8):1315-22. doi: 10.1084/jem.186.8.1315

46. Srivastava P. Interaction of Heat Shock Proteins With Peptides and Antigen Presenting Cells: Chaperoning of the Innate and Adaptive Immune Responses. Annu Rev Immunol (2002) 20:395-425. doi: 10.1146/ annurev.immunol.20.100301.064801

47. Sciacovelli M, Guzzo G, Morello V, Frezza C, Zheng L, Nannini N, et al. The Mitochondrial Chaperone TRAP1 Promotes Neoplastic Growth by Inhibiting Succinate Dehydrogenase. Cell Metab (2013) 17(6):988-99. doi: 10.1016/j.cmet.2013.04.019

48. Marzec M, Eletto D, Argon Y. GRP94: An HSP90-Like Protein Specialized for Protein Folding and Quality Control in the Endoplasmic Reticulum. Biochim Biophys Acta (2012) 3(1823):774-87. doi: 10.1016/j.bbamcr. 2011.10.013

49. Brewer JW, Diehl JA. PERK Mediates Cell-Cycle Exit During the Mammalian Unfolded Protein Response. Proc Natl Acad Sci USA (2000) 97(23):12625-30. doi: 10.1073/pnas.220247197

50. Nakagawa T, Zhu H, Morishima N, Li E, Xu J, Yankner BA, et al. Caspase-12 Mediates Endoplasmic-Reticulum-Specific Apoptosis and Cytotoxicity by Amyloid- $\beta$. Nature (2000) 403(6765):98-103. doi: $10.1038 / 47513$

51. Bae J, Munshi A, Li C, Samur M, Prabhala R, Mitsiades C, et al. Heat Shock Protein 90 Is Critical for Regulation of Phenotype and Functional Activity of Human T Lymphocytes and NK Cells. J Immunol (2013) 190(3):1360-71. doi: 10.4049/jimmunol.1200593

52. Huyan T, Li Q, Dong D-D, Yang H, Zhang J, Huang Q-S, et al. Heat Shock Protein 90 Inhibitors Induce Functional Inhibition of Human Natural Killer Cells in a Dose-Dependent Manner. Immunopharmacol Immunotoxicol (2016) 38(2):77-86. doi: 10.3109/08923973.2015.1119159

53. Sedlacek AL, Kinner-Bibeau LB, Binder RJ. Phenotypically Distinct Helper NK Cells Are Required for Gp96-Mediated Anti-Tumor Immunity. Sci Rep (2016) 6(1):29889. doi: 10.1038/srep29889

54. Multhoff G, Mizzen L, Winchester CC, Milner CM, Wenk S, Eissner G, et al. Heat Shock Protein 70 (Hsp70) Stimulates Proliferation and Cytolytic Activity of Natural Killer Cells. Exp Hematol (1999) 27(11):1627-36. doi: 10.1016/s0301-472x(99)00104-6

55. Multhoff G, Pfister K, Gehrmann M, Hantschel M, Gross C, Hafner M, et al. A 14-Mer Hsp70 Peptide Stimulates Natural Killer (NK) Cell Activity. Cell Stress Chaperones (2001) 6(4):337-44. doi: 10.1379/1466-1268(2001) 006 $<0337$ :AMHPSN $>2.0$. CO; 2

56. Shevtsov M, Pitkin E, Ischenko A, Stangl S, Khachatryan W, Galibin O, et al. Ex Vivo Hsp70-Activated NK Cells in Combination With PD-1 Inhibition Significantly Increase Overall Survival in Preclinical Models of Glioblastoma and Lung Cancer. Front Immunol (2019) 10:454. doi: 10.3389/ fimmu.2019.00454

57. Rothammer A, Sage EK, Werner C, Combs SE, Multhoff G. Increased Heat Shock Protein 70 (Hsp70) Serum Levels and Low NK Cell Counts After Radiotherapy - Potential Markers for Predicting Breast Cancer Recurrence? Radiat Oncol (2019) 14(1):78. doi: 10.1186/s13014-019-1286-0

58. Breloer M, Fleischer B, Bonin Av. In Vivo and In Vitro Activation of T Cells After Administration of Ag-Negative Heat Shock Proteins. J Immunol (1999) 162(6):3141.

59. Daniels GA, Sanchez-Perez L, Diaz RM, Kottke T, Thompson J, Lai M, et al. A Simple Method to Cure Established Tumors by Inflammatory Killing of Normal Cells. Nat Biotechnol (2004) 22(9):1125-32. doi: 10.1038/nbt1007

60. Martine P, Chevriaux A, Derangère V, Apetoh L, Garrido C, Ghiringhelli F, et al. HSP70 Is a Negative Regulator of NLRP3 Inflammasome Activation. Cell Death Dis (2019) 10(4):256-6. doi: 10.1038/s41419-019-1491-7

61. Swanson KV, Deng M, Ting JPY. The NLRP3 Inflammasome: Molecular Activation and Regulation to Therapeutics. Nat Rev Immunol (2019) 19 (8):477-89. doi: 10.1038/s41577-019-0165-0

62. Nizami S, Arunasalam K, Green J, Cook J, Lawrence CB, Zarganes-Tzitzikas T, et al. Inhibition of the NLRP3 Inflammasome by HSP90 Inhibitors. Immunology (2021) 162(1):84-91. doi: 10.1111/imm.13267
63. Shimp SK, Parson CD, Regna NL, Thomas AN, Chafin CB, Reilly CM, et al. HSP90 Inhibition by 17-DMAG Reduces Inflammation in J774 Macrophages Through Suppression of Akt and Nuclear Factor- $\mathrm{kb}$ Pathways. Inflamm Res (2012) 61(5):521-33. doi: 10.1007/s00011-0120442-x

64. Broemer M, Krappmann D, Scheidereit C. Requirement of Hsp90 Activity for IKb Kinase (IKK) Biosynthesis and for Constitutive and Inducible IKK and NF-kb Activation. Oncogene (2004) 23(31):5378-86. doi: 10.1038/ sj.onc. 1207705

65. Graner MW. Chapter Eight - HSP90 and Immune Modulation in Cancer. In: Isaacs J, Whitesell L, editors. Advances in Cancer Research, vol. 129. Academic Press (2016). p. 191-224. doi: 10.1016/bs.acr.2015.10.001

66. Arbore G, West EE, Spolski R, Robertson AAB, Klos A, Rheinheimer C, et al. T Helper 1 Immunity Requires Complement-Driven NLRP3 Inflammasome Activity in CD4 $4^{+}$T Cells. Sci (New York NY) (2016) 352(6292):aad1210aad1210. doi: 10.1126/science.aad1210

67. Ichiyanagi T, Imai T, Kajiwara C, Mizukami S, Nakai A, Nakayama T, et al. Essential Role of Endogenous Heat Shock Protein 90 of Dendritic Cells in Antigen Cross-Presentation. J Immunol (2010) 185(5):2693. doi: 10.4049/ jimmunol.1000821

68. Imai T, Kato Y, Kajiwara C, Mizukami S, Ishige I, Ichiyanagi T, et al. Heat Shock Protein 90 (HSP90) Contributes to Cytosolic Translocation of Extracellular Antigen for Cross-Presentation by Dendritic Cells. Proc Natl Acad Sci (2011), 201108372. doi: 10.1073/pnas.1108372108

69. Kunisawa J, Shastri N. Hsp $90 \alpha$ Chaperones Large C-Terminally Extended Proteolytic Intermediates in the MHC Class I Antigen Processing Pathway. Immunity (2006) 24(5):523-34. doi: 10.1016/j.immuni.2006.03.015

70. Rajagopal D, Bal V, Mayor S, George A, Rath S. A Role for the Hsp90 Molecular Chaperone Family in Antigen Presentation to T Lymphocytes via Major Histocompatibility Complex Class II Molecules. Eur J Immunol (2006) 36(4):828-41. doi: 10.1002/eji.200535326

71. Zhou D, Li P, Lin Y, Lott JM, Hislop AD, Canaday DH, et al. Lamp-2a Facilitates MHC Class II Presentation of Cytoplasmic Antigens. Immunity (2005) 22(5):571-81. doi: 10.1016/j.immuni.2005.03.009

72. Panjwani N, Akbari O, Garcia S, Brazil M, Stockinger B. The HSC73 Molecular Chaperone: Involvement in MHC Class II Antigen Presentation. J Immunol (1999) 163(4):1936.

73. Auger I, Escola JM, Gorvel JP, Roudier J. HLA-DR4 and HLA-DR10 Motifs That Carry Susceptibility to Rheumatoid Arthritis Bind 70-kD Heat Shock Proteins. Nat Med (1996) 2(3):306-10. doi: 10.1038/ nm0396-306

74. Song K-H, Oh SJ, Kim S, Cho H, Lee H-J, Song JS, et al. HSP90A Inhibition Promotes Anti-Tumor Immunity by Reversing Multi-Modal Resistance and Stem-Like Property of Immune-Refractory Tumors. Nat Commun (2020) 11 (1):562. doi: 10.1038/s41467-019-14259-y

75. Zavareh RB, Spangenberg SH, Woods A, Martínez-Peña F, Lairson LL. HSP90 Inhibition Enhances Cancer Immunotherapy by Modulating the Surface Expression of Multiple Immune Checkpoint Proteins. Cell Chem Biol (2021) 28(2):158-68.e155. doi: 10.1016/j.chembiol.2020.10.005

76. Marzec M, Zhang Q, Goradia A, Raghunath PN, Liu X, Paessler M, et al. Oncogenic Kinase NPM/ALK Induces Through STAT3 Expression of Immunosuppressive Protein CD274 (PD-L1, B7-H1). Proc Natl Acad Sci USA (2008) 105(52):20852-7. doi: 10.1073/pnas.0810958105

77. Proia DA, Kaufmann GF. Targeting Heat-Shock Protein 90 (HSP90) as a Complementary Strategy to Immune Checkpoint Blockade for Cancer Therapy. Cancer Immunol Res (2015) 3(6):583-9. doi: 10.1158/23266066.Cir-15-0057

78. Mbofung RM, McKenzie JA, Malu S, Zhang M, Peng W, Liu C, et al. HSP90 Inhibition Enhances Cancer Immunotherapy by Upregulating Interferon Response Genes. Nat Commun (2017) 8(1):451. doi: 10.1038/s41467-01700449-z

79. D’Arrigo P, Russo M, Rea A, Tufano M, Guadagno E, Del Basso De Caro $\mathrm{ML}$, et al. A Regulatory Role for the Co-Chaperone FKBP51s in PD-L1 Expression in Glioma. Oncotarget (2017) 8(40):68291-304. doi: 10.18632/ oncotarget.19309

80. Chou C-W, Yang R-Y, Chan L-C, Li C-F, Sun L, Lee H-H, et al. The Stabilization of PD-L1 by the Endoplasmic Reticulum Stress Protein GRP78 in Triple-Negative Breast Cancer. Am J Cancer Res (2020) 10(8):2621-34. 
81. Multhoff G, Botzler C, Wiesnet M, Müller E, Meier T, Wilmanns W, et al. A Stress-Inducible 72-kDa Heat-Shock Protein (HSP72) Is Expressed on the Surface of Human Tumor Cells, But Not on Normal Cells. Int J Cancer (1995) 61(2):272-9. doi: 10.1002/ijc.2910610222

82. Mambula SS, Calderwood SK. Heat Shock Protein 70 Is Secreted From Tumor Cells by a Nonclassical Pathway Involving Lysosomal Endosomes. J Immunol (2006) 177(11):7849-57. doi: 10.4049/ jimmunol.177.11.7849

83. Mambula SS, Stevenson MA, Ogawa K, Calderwood SK. Mechanisms for Hsp70 Secretion: Crossing Membranes Without a Leader. Methods (2007) 43(3):168-75. doi: 10.1016/j.ymeth.2007.06.009

84. Gehrmann M, Liebisch G, Schmitz G, Anderson R, Steinem C, De Maio A, et al. Tumor-Specific Hsp70 Plasma Membrane Localization Is Enabled by the Glycosphingolipid Gb3. PloS One (2008) 3(4):e1925. doi: 10.1371/ journal.pone.0001925

85. Arispe N, Doh M, Simakova O, Kurganov B, De Maio A. Hsc70 and Hsp70 Interact With Phosphatidylserine on the Surface of PC12 Cells Resulting in a Decrease of Viability. FASEB J (2004) 18(14):1636-45. doi: 10.1096/fi.04-2088com

86. Lancaster GI, Febbraio MA. Exosome-Dependent Trafficking of HSP70: A Novel Secretory Pathway for Cellular Stress Proteins. J Biol Chem (2005) 280 (24):23349-55. doi: 10.1074/jbc.M502017200

87. Clayton A, Turkes A, Navabi H, Mason MD, Tabi Z. Induction of Heat Shock Proteins in B-Cell Exosomes. J Cell Sci (2005) 118(Pt 16):3631-8. doi: $10.1242 /$ jcs. 02494

88. Multhoff G, Hightower LE. Cell Surface Expression of Heat Shock Proteins and the Immune Response. Cell Stress Chaperones (1996) 1(3):167-76. doi: 10.1379/1466-1268(1996)001<0167:cseohs >2.3.co;2

89. Tang X, Chang C, Guo J, Lincoln V, Liang C, Chen M, et al. TumourSecreted Hsp90 $\alpha$ on External Surface of Exosomes Mediates Tumour Stromal Cell Communication via Autocrine and Paracrine Mechanisms. Sci Rep (2019) 9(1):15108. doi: 10.1038/s41598-019-51704-w

90. Chalmin F, Ladoire S, Mignot G, Vincent J, Bruchard M, Remy-Martin J-P, et al. Membrane-Associated Hsp72 From Tumor-Derived Exosomes Mediates STAT3-Dependent Immunosuppressive Function of Mouse and Human Myeloid-Derived Suppressor Cells. J Clin Invest (2010) 120(2):45771. doi: $10.1172 /$ JCI 40483

91. Gobbo J, Marcion G, Cordonnier M, Dias AMM, Pernet N, Hammann A, et al. Restoring Anticancer Immune Response by Targeting Tumor-Derived Exosomes With a HSP70 Peptide Aptamer. J Natl Cancer Inst (2016) 108:(3). doi: $10.1093 /$ jnci/djv330

92. Ullrich SJ, Robinson EA, Law LW, Willingham M, Appella E. A Mouse Tumor-Specific Transplantation Antigen Is a Heat Shock-Related Protein. Proc Natl Acad Sci USA (1986) 83(10):3121-5. doi: 10.1073/pnas.83.10.3121

93. Tsutsumi S, Neckers L. Extracellular Heat Shock Protein 90: A Role for a Molecular Chaperone in Cell Motility and Cancer Metastasis. Cancer Sci (2007) 98(10):1536-9. doi: 10.1111/j.1349-7006.2007.00561.x

94. Tramentozzi E, Ruli E, Angriman I, Bardini R, Campora M, Guzzardo V, et al. Grp94 in Complexes With IgG Is a Soluble Diagnostic Marker of Gastrointestinal Tumors and Displays Immune-Stimulating Activity on Peripheral Blood Immune Cells. Oncotarget (2016) 7(45):72923-40. doi: 10.18632/oncotarget.12141

95. Pagetta A, Tramentozzi E, Tibaldi E, Cendron L, Zanotti G, Brunati AM, et al. Structural Insights Into Complexes of Glucose-Regulated Protein94 (Grp94) With Human Immunoglobulin G. Relevance for Grp94-IgG Complexes That Form In Vivo in Pathological Conditions. PloS One (2014) 9(1):e86198. doi: 10.1371/journal.pone.0086198

96. Tramentozzi E, Montopoli M, Orso G, Pagetta A, Caparrotta L, Frasson M, et al. Stable Complexes Formed by Grp94 With Human IgG Promoting Angiogenic Differentiation of HUVECs by a Cytokine-Like Mechanism. Mol Immunol (2008) 45(13):3639-48. doi: 10.1016/j.molimm.2008.04.020

97. Singh-Jasuja H, Scherer HU, Hilf N, Arnold-Schild D, Rammensee H-G, Toes REM, et al. The Heat Shock Protein Gp96 Induces Maturation of Dendritic Cells and Down-Regulation of Its Receptor. Eur J Immunol (2000) 30(8):2211-5. doi: 10.1002/1521-4141(2000)30:8<2211::AIDIMMU2211>3.0.CO;2-0

98. Pawaria S, Binder RJ. CD91-Dependent Programming of T-Helper Cell Responses Following Heat Shock Protein Immunization. Nat Commun (2011) 2:521-1. doi: 10.1038/ncomms1524
99. Dai J, Liu B, Caudill MM, Zheng H, Qiao Y, Podack ER, et al. Cell Surface Expression of Heat Shock Protein Gp96 Enhances Cross-Presentation of Cellular Antigens and the Generation of Tumor-Specific T Cell Memory. Cancer Immun (2003) 3:1.

100. Doody ADH, Kovalchin JT, Mihalyo MA, Hagymasi AT, Drake CG, Adler AJ. Glycoprotein 96 can Chaperone Both MHC Class I- and Class IIRestricted Epitopes for In Vivo Presentation, But Selectively Primes CD8+ T Cell Effector Function. J Immunol (2004) 172(10):6087-92. doi: 10.4049/ jimmunol.172.10.6087

101. Kovalchin JT, Murthy AS, Horattas MC, Guyton DP, Chandawarkar RY. Determinants of Efficacy of Immunotherapy With Tumor-Derived Heat Shock Protein Gp96. Cancer Immun Arch (2001) 1(1):7.

102. Shinagawa N, Yamazaki K, Tamura Y, Imai A, Kikuchi E, Yokouchi H, et al. Immunotherapy With Dendritic Cells Pulsed With Tumor-Derived Gp96 Against Murine Lung Cancer Is Effective Through Immune Response of CD8 + Cytotoxic T Lymphocytes and Natural Killer Cells. Cancer Immunol Immunother (2008) 57(2):165-74. doi: 10.1007/s00262-007-0359-3

103. Yang Y, Liu B, Dai J, Srivastava PK, Zammit DJ, Lefrançois L, et al. Heat Shock Protein Gp96 Is a Master Chaperone for Toll-Like Receptors and Is Important in the Innate Function of Macrophages. Immunity (2007) 26 (2):215-26. doi: 10.1016/j.immuni.2006.12.005

104. Vabulas RM, Braedel S, Hilf N, Singh-Jasuja H, Herter S, Ahmad-Nejad P, et al. The Endoplasmic Reticulum-Resident Heat Shock Protein Gp96 Activates Dendritic Cells via the Toll-Like Receptor 2/4 Pathway *. J Biol Chem (2002) 277(23):20847-53. doi: 10.1074/jbc.M200425200

105. Li X, Liu Z, Yan X, Zhang X, Li Y, Zhao B, et al. Induction of Regulatory T Cells by High-Dose Gp96 Suppresses Murine Liver Immune Hyperactivation. PloS One (2013) 8(7):e68997. doi: 10.1371/journal.pone.0068997

106. Liu W, Chen M, Li X, Zhao B, Hou J, Zheng H, et al. Interaction of Toll-Like Receptors With the Molecular Chaperone Gp96 Is Essential for Its Activation of Cytotoxic T Lymphocyte Response. PloS One (2016) 11(5): e0155202. doi: 10.1371/journal.pone.0155202

107. Wang Y, Sedlacek AL, Pawaria S, Xu H, Scott MJ, Binder RJ. Cutting Edge: The Heat Shock Protein Gp96 Activates Inflammasome-Signaling Platforms in APCs. J Immunol (2018) 201(8):2209. doi: 10.4049/jimmunol.1800505

108. Chen Y-Q, Li P-C, Pan N, Gao R, Wen Z-F, Zhang T-Y, et al. TumorReleased Autophagosomes Induces $\mathrm{CD}^{+}{ }^{+} \mathrm{T}$ Cell-Mediated Immunosuppression via a TLR2-IL-6 Cascade. J ImmunoTher Cancer (2019) 7(1):178. doi: 10.1186/s40425-019-0646-5

109. Chen C-C, Chen L-L, Li C-P, Hsu Y-T, Jiang S-S, Fan C-S, et al. MyeloidDerived Macrophages and Secreted HSP90 $\alpha$ Induce Pancreatic Ductal Adenocarcinoma Development. Oncoimmunology (2018) 7(5):e1424612e1424612. doi: 10.1080/2162402X.2018.1424612

110. Zou M, Bhatia A, Dong H, Jayaprakash P, Guo J, Sahu D, et al. Evolutionarily Conserved Dual Lysine Motif Determines the Non-Chaperone Function of Secreted Hsp90alpha in Tumour Progression. Oncogene (2017) 36(15):216071. doi: $10.1038 /$ onc. 2016.375

111. Stellas D, El Hamidieh A, Patsavoudi E. Monoclonal Antibody 4C5 Prevents Activation of MMP2 and MMP9 by Disrupting Their Interaction With Extracellular HSP90 and Inhibits Formation of Metastatic Breast Cancer Cell Deposits. BMC Cell Biol (2010) 11:51-1. doi: 10.1186/14712121-11-51

112. Gastpar R, Gross C, Rossbacher L, Ellwart J, Riegger J, Multhoff G. The Cell Surface-Localized Heat Shock Protein 70 Epitope TKD Induces Migration and Cytolytic Activity Selectively in Human NK Cells. J Immunol (2004) 172 (2):972. doi: 10.4049/jimmunol.172.2.972

113. Stangl S, Gross C, Pockley AG, Asea AA, Multhoff G. Influence of Hsp70 and HLA-E on the Killing of Leukemic Blasts by Cytokine/Hsp70 PeptideActivated Human Natural Killer (NK) Cells. Cell Stress Chaperones (2008) 13(2):221-30. doi: 10.1007/s12192-007-0008-y

114. Figueiredo C, Wittmann M, Wang D, Dressel R, Seltsam A, Blasczyk R, et al. Heat Shock Protein 70 (HSP70) Induces Cytotoxicity of T-Helper Cells. Blood (2009) 113(13):3008-16. doi: 10.1182/blood-2008-06162727

115. Xie Y, Bai O, Zhang H, Yuan J, Zong S, Chibbar R, et al. Membrane-Bound HSP70-Engineered Myeloma Cell-Derived Exosomes Stimulate More Efficient CD8(+) CTL- and NK-Mediated Antitumour Immunity Than Exosomes Released From Heat-Shocked Tumour Cells Expressing 
Cytoplasmic HSP70. J Cell Mol Med (2010) 14(11):2655-66. doi: 10.1111/ j.1582-4934.2009.00851.x

116. Diao J, Yang X, Song X, Chen S, He Y, Wang Q, et al. Exosomal Hsp70 Mediates Immunosuppressive Activity of the Myeloid-Derived Suppressor Cells via Phosphorylation of Stat3. Med Oncol (2015) 32(2):35. doi: 10.1007/ s12032-014-0453-2

117. Wachstein J, Tischer S, Figueiredo C, Limbourg A, Falk C, Immenschuh S, et al. HSP70 Enhances Immunosuppressive Function of CD4+CD25+FoxP3+ T Regulatory Cells and Cytotoxicity in CD4+CD25- T Cells. PloS One (2012) 7(12):e51747. doi: 10.1371/journal.pone.0051747

118. Gastpar R, Gehrmann M, Bausero MA, Asea A, Gross C, Schroeder JA, et al. Heat Shock Protein 70 Surface-Positive Tumor Exosomes Stimulate Migratory and Cytolytic Activity of Natural Killer Cells. Cancer Res (2005) 65(12):5238-47. doi: 10.1158/0008-5472.Can-04-3804

119. Multhoff G, Botzler C, Jennen L, Schmidt J, Ellwart J, Issels R. Heat Shock Protein 72 on Tumor Cells: A Recognition Structure for Natural Killer Cells. J Immunol (1997) 158(9):4341. doi: 10.3390/cancers6010042

120. Simhadri VR, Reiners KS, Hansen HP, Topolar D, Simhadri VL, Nohroudi K, et al. Dendritic Cells Release HLA-B-Associated Transcript-3 Positive Exosomes to Regulate Natural Killer Function. PloS One (2008) 3(10):e33777. doi: 10.1371/journal.pone.0003377

121. Lv L-H, Wan Y-L, Lin Y, Zhang W, Yang M, Li G-L, et al. Anticancer Drugs Cause Release of Exosomes With Heat Shock Proteins From Human Hepatocellular Carcinoma Cells That Elicit Effective Natural Killer Cell Antitumor Responses In Vitro. J Biol Chem (2012) 287(19):15874-85. doi: 10.1074/jbc.M112.340588

122. Elmallah MIY, Cordonnier M, Vautrot V, Chanteloup G, Garrido C, Gobbo J. Membrane-Anchored Heat-Shock Protein 70 (Hsp70) in Cancer. Cancer Lett (2020) 469:134-41. doi: 10.1016/j.canlet.2019.10.037

123. Farshbaf M, Khosroushahi AY, Mojarad-Jabali S, Zarebkohan A, Valizadeh H, Walker PR. Cell Surface GRP78: An Emerging Imaging Marker and Therapeutic Target for Cancer. J Control Release (2020) 328:932-41. doi: 10.1016/j.jconrel.2020.10.055

124. Raiter A, Lipovetzki J, Lubin I, Yerushalmi R. GRP78 Expression in Peripheral Blood Mononuclear Cells Is a New Predictive Marker for the Benefit of Taxanes in Breast Cancer Neoadjuvant Treatment. BMC Cancer (2020) 20(1):333. doi: 10.1186/s12885-020-06835-Z

125. Tang $\mathrm{Y}$, Jiang $\mathrm{Q}$, Ou $\mathrm{Y}$, Zhang F, Qing $\mathrm{K}$, Sun $\mathrm{Y}$, et al. BIP Induces Mice CD19hi Regulatory B Cells Producing IL-10 and Highly Expressing PD-L1, FasL. Mol Immunol (2016) 69:44-51. doi: 10.1016/j.molimm. 2015.10.017

126. Corrigall VM, Bodman-Smith MD, Brunst M, Cornell H, Panayi GS. Inhibition of Antigen-Presenting Cell Function and Stimulation of Human Peripheral Blood Mononuclear Cells to Express an Antiinflammatory Cytokine Profile by the Stress Protein BiP: Relevance to the Treatment of Inflammatory Arthritis. Arthritis Rheum (2004) 50(4):1164-71. doi: 10.1002/ art.20134

127. Corrigall VM, Vittecoq O, Panayi GS. Binding Immunoglobulin ProteinTreated Peripheral Blood Monocyte-Derived Dendritic Cells Are Refractory to Maturation and Induce Regulatory T-Cell Development. Immunology (2009) 128(2):218-26. doi: 10.1111/j.1365-2567.2009.03103.x

128. Rosenes Z, Mulhern TD, Hatters DM, Ilag LL, Power BE, Hosking C, et al. The Anti-Cancer IgM Monoclonal Antibody PAT-SM6 Binds With High Avidity to the Unfolded Protein Response Regulator GRP78. PloS One (2012) 7(9):e44927-7. doi: 10.1371/journal.pone.0044927

129. de Ridder GG, Ray R, Pizzo SV. A Murine Monoclonal Antibody Directed Against the Carboxyl-Terminal Domain of GRP78 Suppresses Melanoma Growth in Mice. Melanoma Res (2012) 22:(3). doi: 10.1097/CMR. 0b013e32835312fd

130. Liu R, Li X, Gao W, Zhou Y, Wey S, Mitra SK, et al. Monoclonal Antibody Against Cell Surface GRP78 as a Novel Agent in Suppressing PI3K/AKT Signaling, Tumor Growth, and Metastasis. Clin Cancer Res (2013) 19 (24):6802-11. doi: 10.1158/1078-0432.CCR-13-1106

131. Pilzer D, Fishelson Z. Mortalin/GRP75 Promotes Release of Membrane Vesicles From Immune Attacked Cells and Protection From ComplementMediated Lysis. Int Immunol (2005) 17(9):1239-48. doi: 10.1093/intimm/ dxh300
132. Saar Ray M, Moskovich O, Iosefson O, Fishelson Z. Mortalin/GRP75 Binds to Complement C9 and Plays a Role in Resistance to ComplementDependent Cytotoxicity. J Biol Chem (2014) 289(21):15014-22. doi: 10.1074/jbc.M114.552406

133. Pilzer D, Saar M, Koya K, Fishelson Z. Mortalin Inhibitors Sensitize K562 Leukemia Cells to Complement-Dependent Cytotoxicity. Int J Cancer (2010) 126(6):1428-35. doi: 10.1002/ijc.24888

134. Asea A, Kraeft S-K, Kurt-Jones EA, Stevenson MA, Chen LB, Finberg RW, et al. HSP70 Stimulates Cytokine Production Through a CD14-Dependant Pathway, Demonstrating Its Dual Role as a Chaperone and Cytokine. Nat Med (2000) 6(4):435-42. doi: 10.1038/74697

135. Berthenet K, Boudesco C, Collura A, Svrcek M, Richaud S, Hammann A, et al. Extracellular HSP110 Skews Macrophage Polarization in Colorectal Cancer. Oncoimmunology (2016) 5(7):e1170264-e1170264. doi: 10.1080/ 2162402X.2016.1170264

136. Wang X-Y, Arnouk H, Chen X, Kazim L, Repasky EA, Subjeck JR. Extracellular Targeting of Endoplasmic Reticulum Chaperone GlucoseRegulated Protein 170 Enhances Tumor Immunity to a Poorly Immunogenic Melanoma. J Immunol (2006) 177(3):1543. doi: 10.4049/ jimmunol.177.3.1543

137. Wang H, Pezeshki AM, Yu X, Guo C, Subjeck JR, Wang X-Y. The Endoplasmic Reticulum Chaperone GRP170: From Immunobiology to Cancer Therapeutics. Front Oncol (2015) 4:377. doi: 10.3389/ fonc.2014.00377

138. Wang H, Yu X, Guo C, Zuo D, Fisher PB, Subjeck JR, et al. Enhanced Endoplasmic Reticulum Entry of Tumor Antigen Is Crucial for CrossPresentation Induced by Dendritic Cell-Targeted Vaccination. J Immunol (2013) 191(12):6010-21. doi: 10.4049/jimmunol.1302312

139. Wang X-Y, Kazim L, Repasky EA, Subjeck JR. Immunization With TumorDerived ER Chaperone Grp170 Elicits Tumor-Specific CD8+ T-Cell Responses and Reduces Pulmonary Metastatic Disease. Int J Cancer (2003) 105(2):226-31. doi: 10.1002/ijc.11058

140. Flohé SB, Brüggemann J, Lendemans S, Nikulina M, Meierhoff G, Flohé S, et al. Human Heat Shock Protein 60 Induces Maturation of Dendritic Cells Versus a Th1-Promoting Phenotype. J Immunol (2003) 170(5):2340. doi: 10.4049/jimmunol.170.5.2340

141. Quintana FJ, Cohen IR. The HSP60 Immune System Network. Trends Immunol (2011) 32(2):89-95. doi: 10.1016/j.it.2010.11.001

142. Osterloh A, Kalinke U, Weiss S, Fleischer B, Breloer M. Synergistic and Differential Modulation of Immune Responses by Hsp60 and Lipopolysaccharide*. J Biol Chem (2007) 282(7):4669-80. doi: 10.1074/ jbc.M608666200

143. Zanin-Zhorov A, Bruck R, Tal G, Oren S, Aeed H, Hershkoviz R, et al. Heat Shock Protein 60 Inhibits Th1-Mediated Hepatitis Model via Innate Regulation of Th1/Th2 Transcription Factors and Cytokines. J Immunol (2005) 174(6):3227. doi: 10.4049/jimmunol.174.6.3227

144. Quintana FJ, Mimran A, Carmi P, Mor F, Cohen IR. HSP60 as a Target of Anti-Ergotypic Regulatory T Cells. PloS One (2008) 3(12):e4026-6. doi: 10.1371/journal.pone.0004026

145. Cohen-Sfady M, Nussbaum G, Pevsner-Fischer M, Mor F, Carmi P, ZaninZhorov A, et al. Heat Shock Protein 60 Activates B Cells via the TLR4MyD88 Pathway. J Immunol (2005) 175(6):3594. doi: 10.4049/ jimmunol.175.6.3594

146. Feng H, Zeng Y, Graner MW, Katsanis E. Stressed Apoptotic Tumor Cells Stimulate Dendritic Cells and Induce Specific Cytotoxic T Cells. Blood (2002) 100(12):4108-15. doi: 10.1182/blood-2002-05-1389

147. Zanin-Zhorov A, Tal G, Shivtiel S, Cohen M, Lapidot T, Nussbaum G, et al. Heat Shock Protein 60 Activates Cytokine-Associated Negative Regulator Suppressor of Cytokine Signaling 3 in T Cells: Effects on Signaling, Chemotaxis, and Inflammation. J Immunol (2005) 175(1):276. doi: 10.4049/jimmunol.175.1.276

148. Yang H-Z, Cui B, Liu H-Z, Mi S, Yan J, Yan H-M, et al. Blocking TLR2 Activity Attenuates Pulmonary Metastases of Tumor. PloS One (2009) 4(8): e6520. doi: 10.1371/journal.pone.0006520

149. Vidyasagar A, Wilson NA, Djamali A. Heat Shock Protein 27 (HSP27): Biomarker of Disease and Therapeutic Target. Fibrogene Tissue Repair (2012) 5(1):7-7. doi: 10.1186/1755-1536-5-7 
150. Banerjee S, Lin C-FL, Skinner KA, Schiffhauer LM, Peacock J, Hicks DG, et al. Heat Shock Protein 27 Differentiates Tolerogenic Macrophages That May Support Human Breast Cancer Progression. Cancer Res (2011) 71 (2):318. doi: 10.1158/0008-5472.CAN-10-1778

Conflict of Interest: The authors declare that the research was conducted in the absence of any commercial or financial relationships that could be construed as a potential conflict of interest.

Publisher's Note: All claims expressed in this article are solely those of the authors and do not necessarily represent those of their affiliated organizations, or those of the publisher, the editors and the reviewers. Any product that may be evaluated in this article, or claim that may be made by its manufacturer, is not guaranteed or endorsed by the publisher.

Copyright (c) 2021 Albakova and Mangasarova. This is an open-access article distributed under the terms of the Creative Commons Attribution License (CC BY). The use, distribution or reproduction in other forums is permitted, provided the original author(s) and the copyright owner(s) are credited and that the original publication in this journal is cited, in accordance with accepted academic practice. No use, distribution or reproduction is permitted which does not comply with these terms. 